\title{
Contaminants in aged pesticide grade dichloromethane interfering in herbicide residue analysis and a method for their removal'
}

\author{
James A. Singmaster, $I I I^{2}$
}

\begin{abstract}
A procedure developed for analyses of persistant herbicide residues in soil samples was found to give poor recoveries and extra peaks in gas chromatograms from fortified samples after initial studies had shown acceptable recoveries and no extra peaks. The problem was also found in a "solvent only" sample fortified with prometryn and metribuzin. These two herbicides were then shown to be altered by merely mixing with an aged pesticide grade dichloromethane being used for extractions. Contaminant(s), apparently formed in aged solvent to cause the extra peaks, can be removed by extracting dichloromethane, immediately before it is used, with $10 \%$ sodium carbonate solution. Chromatograms are presented to illustrate the effects of the contaminant(s) and their removal by such extraction with recoveries of 0 to 50-percent raised to above 75 percent for the two herbicides when clean solvent is used for extractions. With one of the oldest bottles of dichloromethane in stock for 8 years, the odor of dichlormethane was masked by a pungent acidic odor, which was removed by the sodium carbonate extraction.

The contaminant(s) may arise with time in the pesticide grade solvent because of lack or degradation of an additive present in some other grades of this solvent. A literature review for data to explain the contaminants revealed numerous inhibitors, stabilizers and preservatives added at varying levels in many grades of dichloromethane but little information available on how these additives function, or whether they or their altered products may interfere in analyses. The data herein reinforce the report that careful evaluation of dichloromethane for additives or degradation must be made before using this solvent for extractions in trace organic analyses.
\end{abstract}

\section{RESUMEN}

Método para desplazar contaminantes del pesticida dicloromefano que interfieren en el análisis de residuos de herbicidas

Se encontró que un procedimiento desarrollado para el análisis de residuos de herbicidas persistentes en suelos daba recuperaciones pobres $y$ cromatogramas con señales extras en muestras fortificadas. En los estudios iniciales se lograron recuperaciones y cromatogramas aceptables. El problema sugríb también al analizar muestras del disolvente fortalecido con prometryn y metribuzin. Estos dos herbicidas sufren cambios al mezclarlos con diclorometano envejecido, grado herbicida, que se usa para hacer ex-

'Manuscript submitted to Editorial Board 17 October 1988.

${ }^{2}$ Associate Investigator, Department of Crop Protection. 
tracciones. Los contaminantes causantes del problema se pueden eliminar mediante extracción del diclorometano con una solución de carbonato de sodio al $10 \%$. Se presentan cromatogramas para demostrar el efecto del contaminante y su remoción mediante extracción, para los dos herbicidas usando un disolvente limpio para las extracciones. Las recuperaciones con disolvente limpio aumentaron a más de $75 \%$ comparadas con recuperaciones de 0 a $50 \%$ con el disolvente contarninado. En una de las botellas de diclorometano que estuvo almacenada por 8 años, el olor de diclorometano estaba enmascarado por un olor ácido picante, el cual se eliminó en la extracción con la solución de carbonato de sodio.

la confaminación puede surgir con el tiempo en el disolvente grado pesticida debido a la ausencia o a la degradación de un aditivo que se encuentra en el disolvente de atros grados de pureza. En la búsqueda de dafos en la literatura que explicaran el comportamiento de los contaminantes se encontraron numerosos inhibidores, estabilizadores y preservativos que se añaden en diferentes porporciones al diclorometano de diferentes grados de pureza y se encontró muy poca información de cómo estos aditivos funcionan y si ellos o sus productos degradados interfieren en los análisis. Los datos aquí incluidos y la revisión de bibliografía indican que hay que evaluar el diclorometano cuidadosamente para la presencia de aditivos o sus degradaciones antes de usar el disolvente en el análisis de trazas de compuestos orgánicos.

\section{INTRODUCTION}

Some requests for analyses of soils for certain persistent herbicides used principally in sugarcane lands (6) were made to the Agricultural Experiment Station in 1983-5 as the land use pattern was being shifted to vegetables, some of which were experiencing damage suggestive of herbicide carryover. A procedure, modified somewhat as detailed in Materials and Methods from those reported for triazines (7) and metribuzin (1), was adapted for their analyses after fortified soil samples of several Mollisols from the south central area of Puerto Rico showed good recoveries with the modified procedure. The major herbicides of concern were diuron and ametryn from cane land, along with prometryn and metribuzin $^{3}$ used in pigeon peas by some farmers. Diuron was detected by thin layer chromatography, whereas the other three were detected by gas chromatography.

Initially in 1984-5, the liquid phase for gas chromatography was $5 \%$ Carbowax 20M, which had problems because of rapid deterioration. A better liquid phase, $5 \%$ cyclohexanol-dimethanol succinate was found to give similar separations with much less deterioration. With the improved liquid phase for gas chromatography, the next step was to check applicability of the procedure to a variety of soils. Fortified samples of other soils collected in late 1986 and early 1987 were analyzed by the modified procedure with poor recoveries of prometryn and metribuzin and with

${ }^{3}$ Chemical names [Chem. Abst. Nos.]: N'-(3,4-dichlorophenyl)-N,N-dimethylurea [33054-1]; N-ethyl-N'-(1-methylethyl)-6-(methylthio)-1,3,5-triazine-2,4-diamine [834-12-8]; $\mathrm{N}, \mathrm{N}^{\prime}$-bis(1-methylethyl)-6-(methylthio)-1,3-5-triazine-2,4-diamine [7287-19-6] and 4-amino6-(1,1-dimethylethyl)-3-(methylthio)-1,2,4-triazine-5(4H)-one[21087-64-9], respectively. 
two additional peaks appearing in chromatograms of extracts from fortified, but not from unfortified soil samples.

At first, the fortification-equilibration step to prepare samples for recovery studies was suspected of having been done improperly. Then, however, a non-soil sample with added prometryn and metribuzin was found to give low recoveries of the herbicides plus the added peaks, which had not been seen in earlier such samples. These results strongly suggested that a reagent in the procedure had become contaminated.

Data herein reported indicate that some aged pesticide grade dichloromethane had undergone some type of decomposition to form contaminants causing the altered recoveries. Because of the similarity of this solvent to chloroform, which readily degrades to phosgene (5), the formation of formyl chloride in the dichloromethane was suspected as a major contaminant. Since formyl chloride and several related compounds are acidic, a $10 \%$ sodium carbonate extraction was tested on the contaminated solvent, and the extracted solvent was found to allow recoveries to return to proper levels without extra peaks in fortified samples.

\section{MATERIALS AND METHODS}

Soil samples were collected at three locations in Puerto Rico: at Fortuna, in a Mollisol (San Antón); at Isabela, in an Oxisol (Coto), and at Lajas, in a Vertisol (Fraternidad). The Oxisol with 23\% moisture and the Vertisol with 27\% moisture at sampling were air dried in sunlight for 3-4 hours. These samples lost $15-20 \%$ of their weight to allow them to pass through a $2 \mathrm{~mm}$ mesh screen, through which the Mollisol with $10 \%$ moisture at sampling was passed without drying. Samples were stored in the refrigerator until used.

Standards for fortification and gas chromatography were prepared for prometryn (98.8\%) and metribuzin (99.5\%) by dissolving weighed amounts in methanol-distilled, pesticide or ACS grade. Appropriate dilutions in methanol were made to obtain one standard solution of $20 \mathrm{p} / \mathrm{m}$ prometryn and $5 \mathrm{p} / \mathrm{m}$ metribuzin, and five fold dilution of this solution provided a standard at the 4 and $1 \mathrm{p} / \mathrm{m}$ levels, respectively. Five $\mathrm{ml}$ of the 20-5 solution was added to $50 \mathrm{~g}$ of soil sample that did not need drying and to $45 \mathrm{~g}$ of dried soil sample to which $5 \mathrm{ml}$ of water was added to make $50 \mathrm{~g}$ of soil at close to the water level of the sample as taken. This resulted in fortified samples containing $2 \mathrm{p} / \mathrm{m}$ of prometryn and $0.5 \mathrm{p} / \mathrm{m}$ of metribuzin. The same procedure using either $1 \mathrm{ml}$ of the $20-5$ or $5 \mathrm{ml}$ of 4-1 solution resulted in fortified samples at the 0.4 and 0.1 levels. These were thoroughly mixed, and some were allowed to stand 48-72 hours at room temperature to allow for some equilibration with soil adsorption sites.

Soil samples of $50 \mathrm{~g}$ were transferred to $500-\mathrm{ml}$ round bottom flasks to which $150 \mathrm{ml}$ of distilled or ACS grade acetonitrile, $50 \mathrm{ml}$ of distilled 
water and $1 \mathrm{~g}$ of zinc acetate dihydrate were added. "Solvent only" recovery samples were prepared by placing appropriate amounts of the standards in methanol in 500-ml flasks and adding the same quantities of reagents. The flasks were placed in heating mantles and connected to water cooled reflux condensors. The samples after the addition of boiling chips were refluxed for one hour, during which time the flasks in the mantles were shaken vigorously for several seconds to loosen any possible stuck soil. After reflux, and some cooling of the samples, $5-10 \mathrm{ml}$ of acetonitrile was flushed down the condensors. Samples were filtered by vacuum through two Whatman No. $541^{4}$ filter papers in Buchner funnels. Flasks were rinsed twice with $25 \mathrm{ml}$ of acetonitrile, which was poured on the collected soil in the funnels. Collected filtrates in 1-L round bottom flasks were stripped of acetonitrile-water azeotrope on rotary vacuum evaporators. This required $15-20 \mathrm{~min}$ with some warming to reach $25-50$ $\mathrm{ml}$ of residual liquids.

The liquids were transferred to funnels containing S. \& S. No. 581 fluted filters with the funnels draining into 125-ml separatory funnels with Teflon stopcocks. The flasks were rinsed with distilled water (15-20 $\mathrm{ml}$ ) that was filtered into the separatory funnels and then were rinsed with 25-ml portions of pesticide grade (PG) dichloromethane that had been in storage for 6-9 years. After water rinses had drained from filters, dichloromethane rinses were transferred to the filters. Filters were pierced with a syringe needle to make one or two holes in each for the solvent to drain. After first solvent rinses drained, second rinses of 25 $\mathrm{ml}$ in flasks were passed to filters. When all solvent had drained, filter funnels were removed, and separatory funnels shaken carefully and vented several times in the first 10-15 seconds. After being shaken for $1 \mathrm{~min}$ or more, funnels were allowed to stand for separation of lower solvent layers, which then were transferred to a second set of 125-ml separatory funnels. Second extractions with $25 \mathrm{ml}$ of solvent were done on the water in the first funnels; lower layers were transferred to the second set of funnels.

The combined extracts in the second funnels were shaken with $25 \mathrm{ml}$ of $0.1 \mathrm{~N}$ sodium hydroxide solution for $1 \mathrm{~min}$, and the funnels allowed to stand for layers to separate. Lower layers were drained into a third set of 125-ml separatory funnels. Occasionally, a sizeable foamy interface between layers occurred in this washing. After the clear lower layers were drained, a few $\mathrm{ml}$ of dichloromethane was added to the water and foam. A little genile rocking of the funnel usually caused the foam to break up so that the rest of the lower layer could be passed to the third

Trade names in this publication are used only to provide specific information. Mention of a trade name does not constitute a warranty of equipment or materials by the Agricultural Experiment Station of the University of Puerto Rico, nor is this mention a statement of preference over other equipment or materials. 
funnel with little or no foam present. Sometimes a few $\mathrm{ml}$ of saturated chloride solution was needed if the foam did not break up well with the added solvent. Distilled water $(50 \mathrm{ml})$ was added to the third set of funnels, which were shaken for $1 \mathrm{~min}$ and then allowed to stand for separations.

Low layers were drained into filter funnels $(75 \mathrm{~mm} \mathrm{0.D.)} \mathrm{that} \mathrm{had}$ small plugs of glass wool with 2-cm layers of anhydrous sodium sulfate, through which the solvent drained into $250-\mathrm{ml}$ round bottom flasks. After solvent layers had drained through the drying agent, approximately 20 $\mathrm{ml}$ of solvent was flushed through the agent. Collected solvent was stripped by vacuum on rotary evaporators until a trace of film remained in the flasks. Methanol $(3 \mathrm{ml}$ ) was mixed with the residues and then removed by evaporation overnight, or by stripping under vacuum (all traces of dichloromethane have to be removed to prevent prolonged disruption of the base line in gas chromatographic analyses). Residues were then transferred with 1-2 ml of methanol to 5-ml volumetric flasks, which were filled to the mark with several succeeding 1-ml methanol washings of round bottom flasks. After being shaken, extracts were ready for gas chromatogxaphic analyses and were stored in a refrigerator if not analyzed within 48 hours.

Studies to show the contamination of dichloromethane and the elimination of its effects were done by taking $5 \mathrm{ml}$ of the $20-5 \mathrm{p} / \mathrm{m}$ solution of prometryn and metribuzin and adding it to $50 \mathrm{ml}$ of dichloromethane, cleaned or uncleaned. The solvents were stripped under vacuum just to dryness, and $3 \mathrm{ml}$ of methanol were added and stripped to dryness. Residues were transferred in methanol to $5-\mathrm{ml}$ volumetric flasks, which were filled to the mark with two to three 1-ml rinses of the flasks used for the stripping. The presence and concentration of prometryn and metribuzin were determined by gas chromatography against standards. Also a "solvent only" recovery sample was split after the acetonitrile stripping with one half extracted using dichloromethane directly from the bottle, and the other half by the cleaned solvent as described next. Dichloromethane (9 volumes) was extracted with 1 volume of $10 \%$ sodium carbonate (A.C.S. grade) solution followed by 1 volume of distilled water and then 1 volume of saturated sodium chloride (A.C.S. grade) solution. In all three extractions, approximately $10 \mathrm{ml}$ of solvent was left in the separatory funnels to be discarded with the upper water layers.

The gas chromatographic analyses were done on a Tracor 560 instrument equipped with a Tracor 700 Hall electrolytic conductivity detector set for nitrogen detection. The hydrogen supply system for the reaction tube in the furnace was altered by removing the hydrogen line after its rotameter and attaching the line to a Swagelok tee connection. A new line from the hydrogen rotameter was attached to the second connector on the tee. The third connector of the tee was attached to a toggle valve 


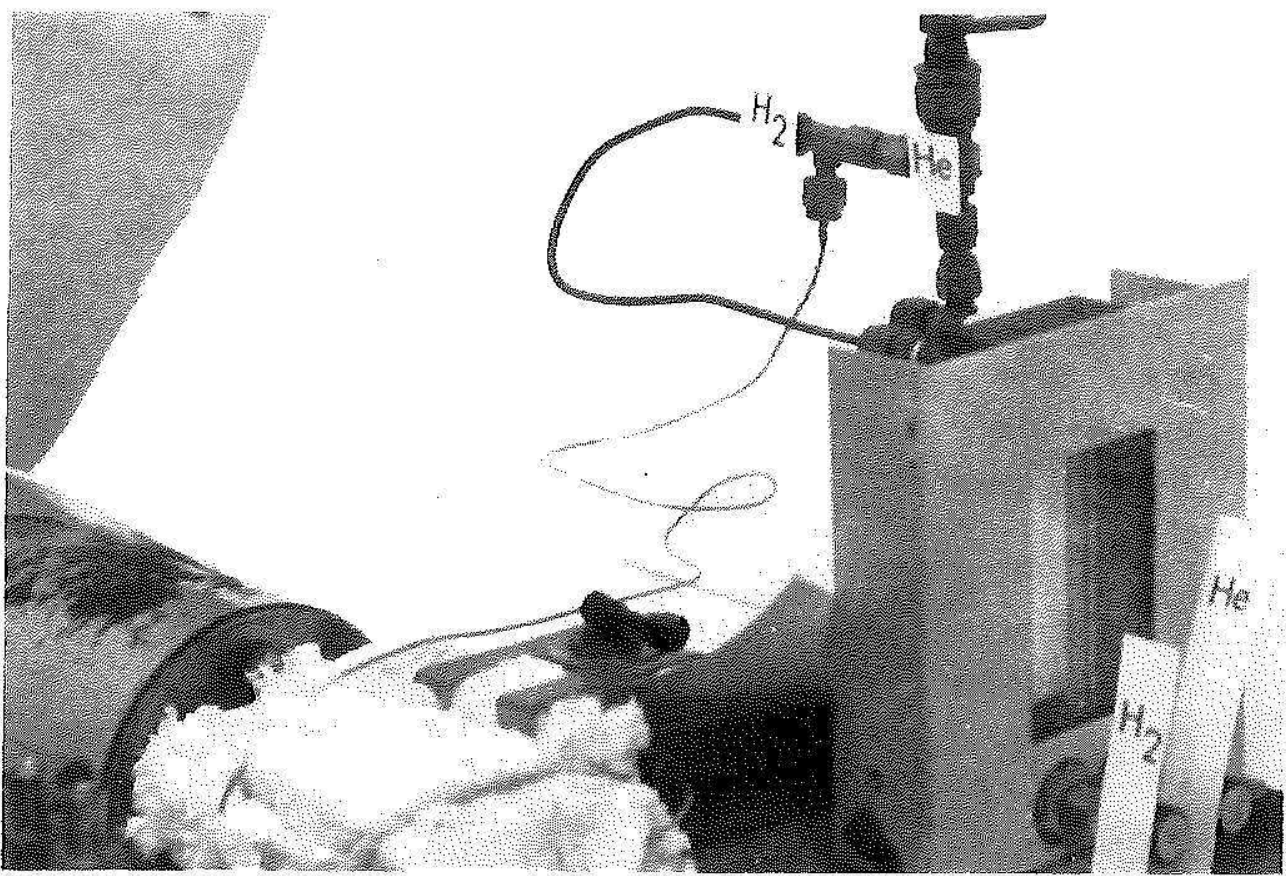

Fic. 1.-Photo showing on Tracor 560 Gas Chromatogxaph helium makeup gas line with value and tee connector to the original hydrogen line as described in Materials and Methods.

that connected to the outlet from the air rotameter. The inlet to the air rotameter was attached to a line connected by a second tee to the helium line used for carrier (fig. 1). The toggle valve attached here was opened and closed together with the vent toggle valve installed in the original Hall unit so that helium flow through the furnace and detector cell was maintained close to constant when venting carrier gas carrier with volatiles from injections.

The conditions for the analyses were as follows:

Column : Glass, $90 \mathrm{~cm} \times 0.2 \mathrm{~cm} \mathrm{1.D.} \mathrm{packed} \mathrm{with} 5 \%$ cyclohexane-dimethanol succinate on 120-140 mesh Gas Chrom Q and conditioned for 24 hours at $225^{\circ} \mathrm{C}$.

$\begin{array}{ll}\text { Temperatures } & \text { Injection port }-225^{\circ} \mathrm{C} \\ & \text { Outlet line }-275^{\circ} \mathrm{C} \\ \text { Gases } & : \text { Helium carrier }-40 \mathrm{ml} / \mathrm{min} \\ & \text { Helium makeup }-40 \mathrm{ml} / \mathrm{min} \\ & \text { Hydrogen reactant }-40 \mathrm{ml} / \mathrm{min}\end{array}$

Oven $-210^{\circ} \mathrm{C}$

Furnace $-820-40^{\circ} \mathrm{C}$

Reaction Tube : Quartz with nickel wire catalyst and potassium hydroxide scrubber as supplied by Tracor for nitrogen detection.

Electrolyte : Propanol-1 $(25 \%)$ in distilled water pumped at 0.5 $\mathrm{ml} / \mathrm{min}$ through ion exchange mixture prepared for nitrogen detection according to Tracor's instructions 
(2). Generally this had to pump overnight after starting to get a stable baseline with conductivity setting at 10 and attenuator setting at 2 . After the injection of 20-30 samples the Teflon tube between furnace and cell may need to be changed or washed to eliminate increasingly erratic behavior in the baseline.

Recorder : Westronics MT Recorder set at 1 millivolt with chart speed of $0.63 \mathrm{~cm} / \mathrm{min}(0.25 \mathrm{in} / \mathrm{min})$.

Both toggle valves were raised together, the sample of 2-10 $\mu \mathrm{l}$ was injected, and after approximately $1 \mathrm{~min}$ the toggle valves were lowered together. The conductivity setting was 10 , and the initial attenuator setting was $16 \mathrm{X}$. Prometryn's elution time was $3.4 \mathrm{~min}$. At 4.5-5.0 min the attenuator setting was changed to $4 \mathrm{X}$ to increase response for metribuzin, which eluted at $6.0 \mathrm{~min}$. After two or three samples, a standard was injected to evaluate whether response was maintained and to establish a standard curve for quantitation, which was done by measuring peak heights and plotting them versus concentration for each herbicide on standard gxaph paper (fig. 2).

\section{RESULTS AND DISCUSSION}

When the abnormal results appeared, the analytical procedure led to good recoveries for the Mollisol after the change to the 5\% cyclohexanedimethanol succinate liquid phase for the column packing. The Oxisol and Vertisol were being tested to verify and expand the procedure, and chromatograms of extracts from fortified and unfortified samples are shown in figures 3 and 4 with chromatograms of prometryn and metribuzin standards, the peak heights of which should have been matched by fortified samples if $100 \%$ recovery occurred. Recoveries are indicated as being from $0-50 \%$ by comparison to the standards, and peaks at 2 and 5.1 min retention time are the major peaks compared to prometryn (3.8 $\mathrm{min}$ ) and metribuzin $(6.0 \mathrm{~min})$. These peaks not seen in the unfortified samples apparently represent altered products from prometryn and/or metribuzin.

As a check on the effect of the equilibration period, a second set of soil samples included some fortified samples subjected to the procedure without an equilibration period. Results confirmed the low recoveries and the presence of the peak at 2.0 minutes. A third set was run that included a "solvent only" sample with the two herbicides. This sample again showed poor recoveries and extra peaks indicating that problem could be attributed to chemicals, which developed contamination after the initial work in 1984-85.

A bottle of pesticide grade (PG) dichloromethane, opened just prior to use for some of the samples in the third set, was then tested by adding 


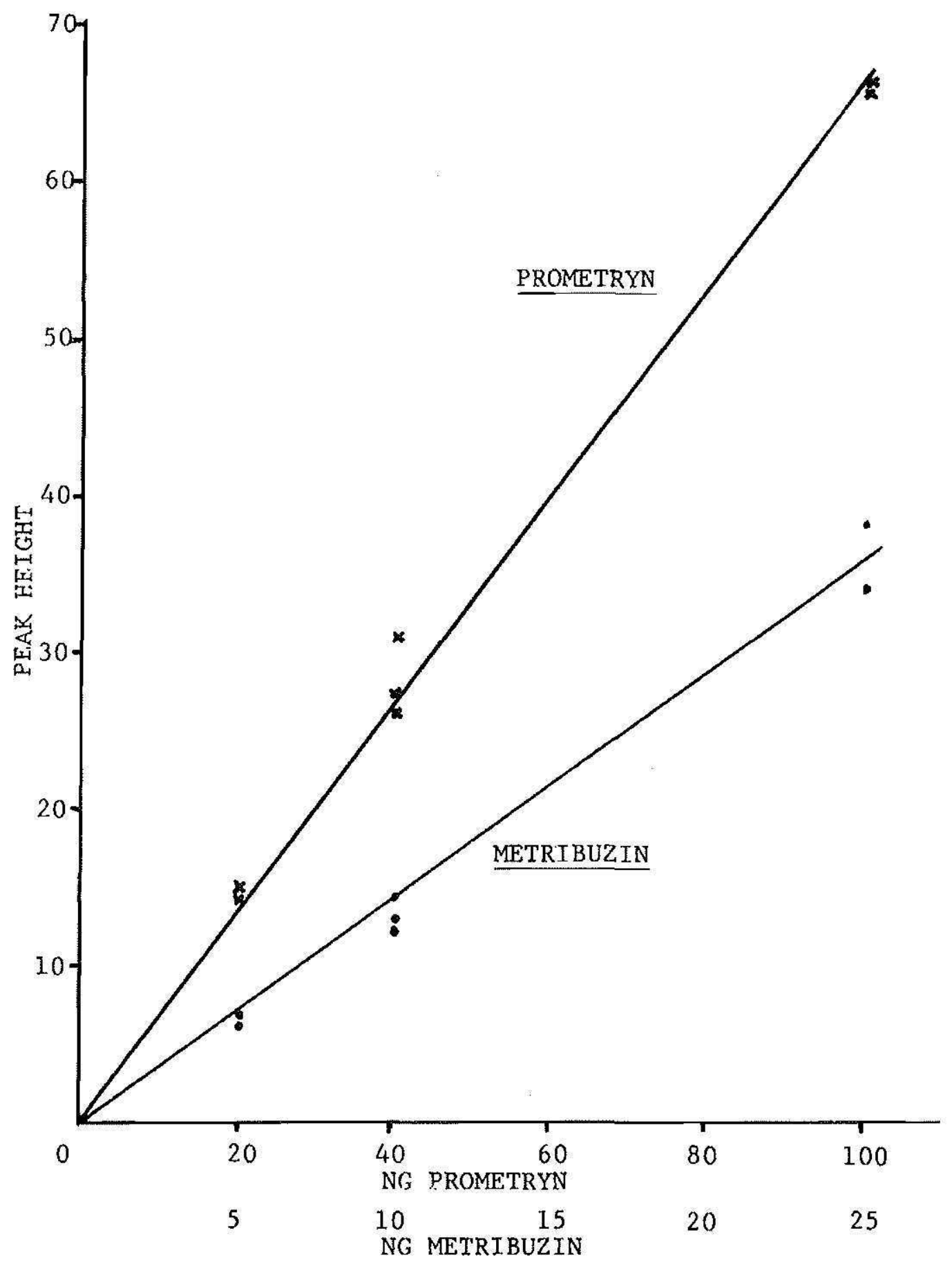

FIG. 2.-Standard curves of recorder response as concentration of prometryn and metmubuzin under conditions described in Materials and Methods.

$50 \mathrm{ml}$ to $5 \mathrm{ml}$ of the $20 \mathrm{p} / \mathrm{m}$ prometryn $-5 \mathrm{p} / \mathrm{m}$ metribuzin standard in methanol and stripping solvents by vacuum. A chromatogram of the residue (fig. 5-c) made up to $5 \mathrm{ml}$ in methanol revealed zero recoveries of prometryn and metribuzin and the extra peaks, principally the one elut- 
J. Agric. Univ. P.R. vol. 75, NO. 4, OCTOBER, 1991

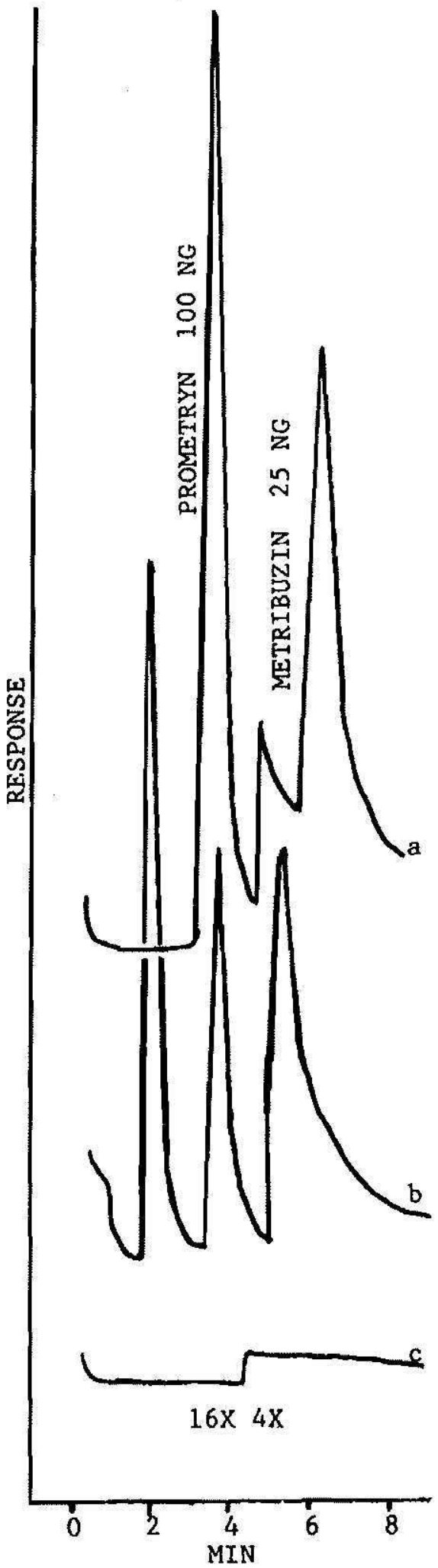

Fig. 3.-Chromatograms of standards (a) and Isabela soil extracts - fortified (b) with poor recoveries and unfortified $c$ ). 


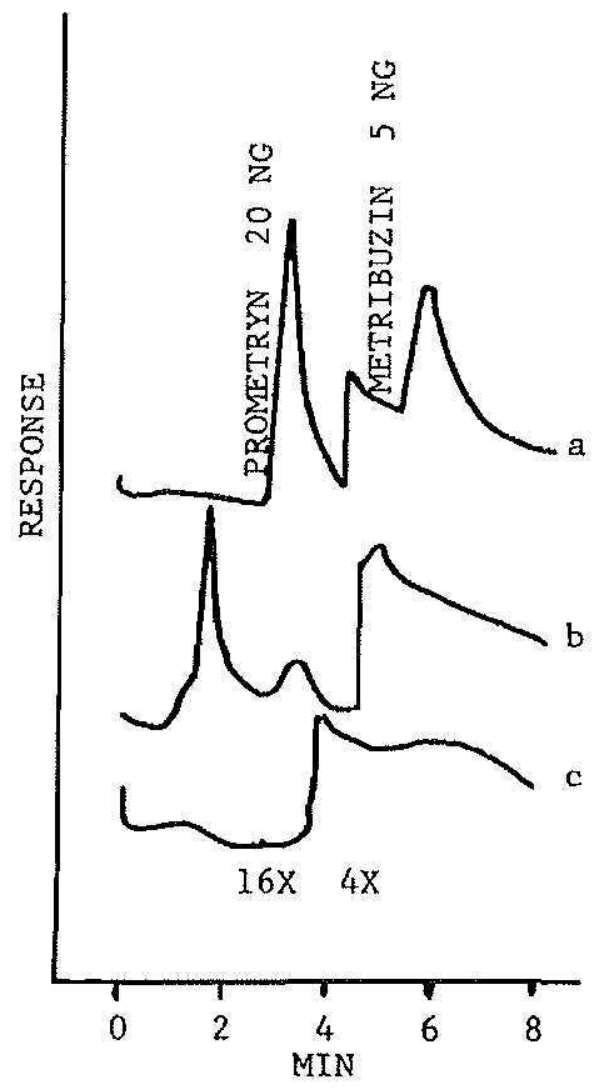

FIG. 4.-Chromatograms of standards (a) and Lajas soil extracts - fortified (b) with poor recoveries and unfortified (c).

ing at $2.0 \mathrm{~min}$, thereby pinpointing the dichloromethane as the problem. Another bottle of older P.G. dichloromethane was opened and tested with similar results indicating that all stocks on hand were probably contaminated. The older bottle, in storage 8-9 years, had a strong acidic odor that completely masked the sweetish odor of dichloromethane, which returned after the extraction by the sodium carbonate solution as described in Materials and Methods.

Since acidic compounds ought to be removed by a base extraction of the solvent, the procedure with $10 \%$ sodium carbonate solution was developed as described in Materials and Methods to apply to some of the contaminated solvent, which after being cleaned, was tested in the manner described above. The residue taken up in $5 \mathrm{ml}$ of methanol showed in its chromatogram (fig. 5 -b) close to $100 \%$ recoveries with no extra peaks compared to the standards of chromatogram (fig. 5-a). Further confirmation of the effectiveness of the cleanup is shown (fig. 6) in which a "solvent only" sample with prometryn and metribuzin was taken to the dichloromethane extraction step. The sample was halved, with one part extracted by using cleaned solvent and the other part extracted by using solvent from the bottle. The chromatogram (fig. 6-b) of the standards 


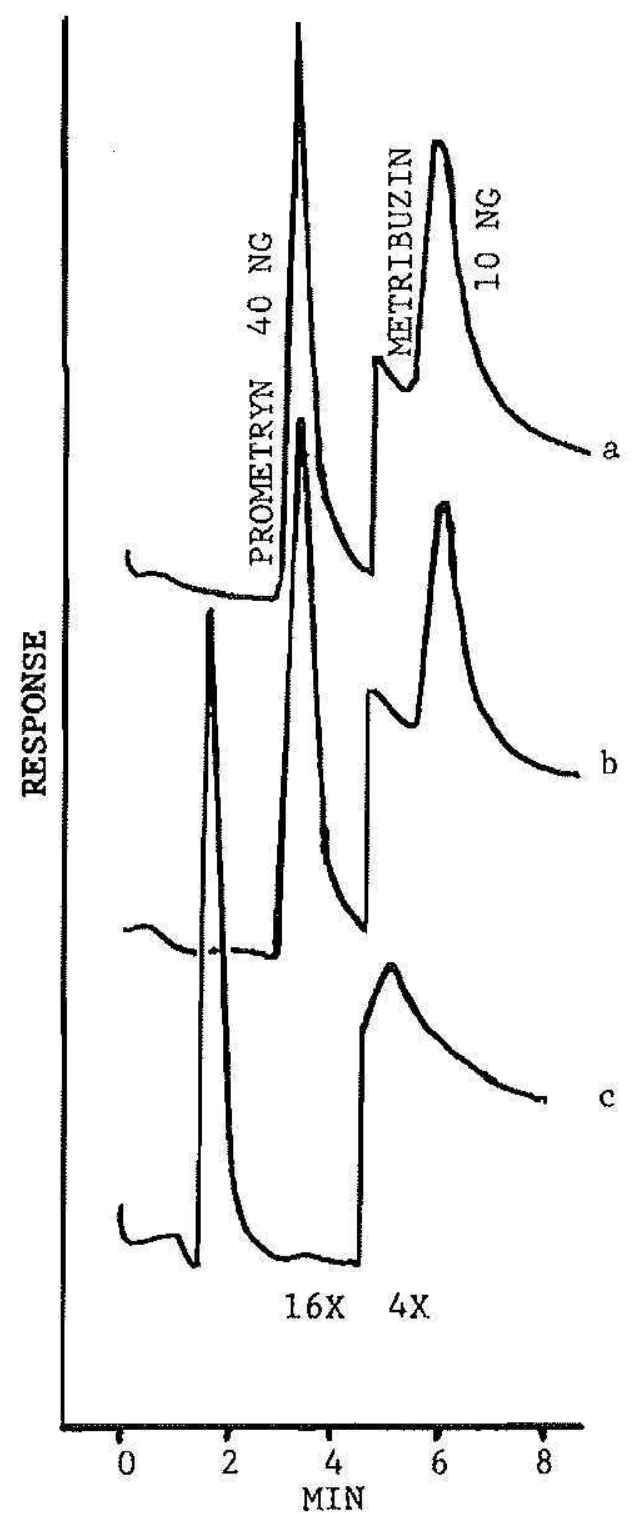

FiG. 5.-Chromatograms of standards (a) and standard recoveries from cleaned (b) and uncleaned (c) dichloromethane.

subjected to cleaned solvent extraction shows normal recoveries compared to the standard solution and no extra peaks, whereas the standards subjected to uncleaned solvent extraction have poor recoveries and the extra peak as seen in the chromatogram (fig. 6-c). Chromatograms of extracts from fortified Oxisol (fig. 7) and Vertisol (fig. 8) samples show the differences in recoveries and extra peaks when cleaned or uncleaned dichloromethane was used. Table 1 gives the percentage recoveries from the fortified samples extracted with cleaned or uncleaned dichloromethane, showing that the procedure gives good recoveries if the dichloromethane is decontaminated as described. 


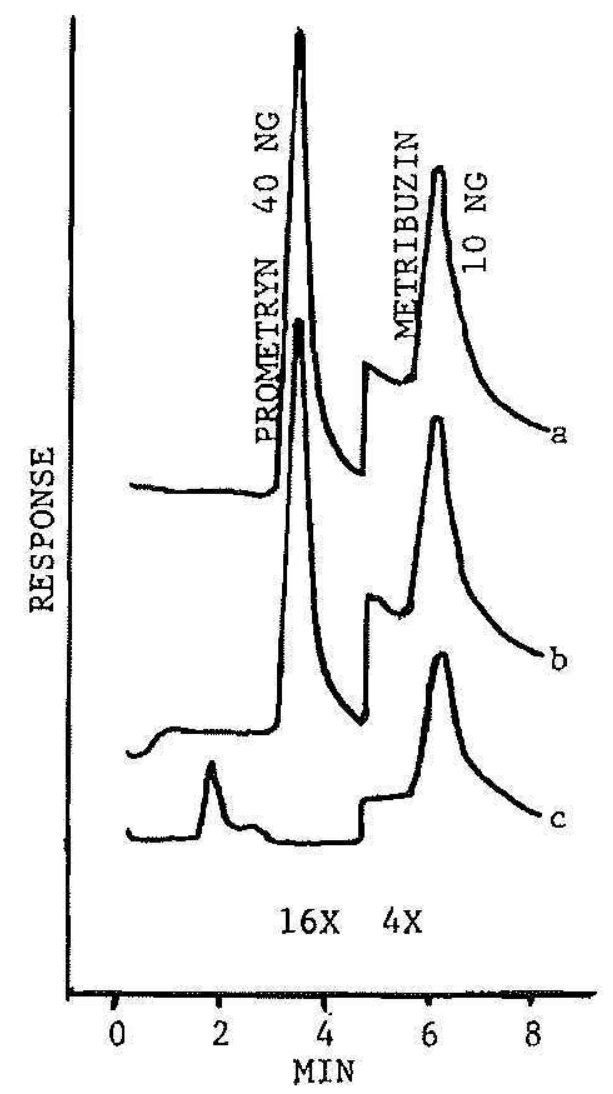

FIG. 6.-Chromatograms of standards (a) and fortified split solvent only sample extracted with cleaned (b) and uncleaned (c) dichlormethane.

The recoveries of the two herbicides in the chromatograms shown in the various figures are quite erratic when extracted with uncleaned solvent as are the appearances of the two extra peaks. Such variations probably reflect differences in contact times between the herbicides and the solvent, and in the uncleaned solvent being mixed directly with the standard solution, the water extracts or the sample extracts, the last of which may have other chemicals to react with the contaminants. The extra peaks with shorter retention times than those of the two herbicides suggest simple derivatives which are less polar, perhaps from a reaction of the herbicides with formyl chloride.

A review of literature and company product data on dichloromethane was undertaken to find whether the problem had been reported before, and whether the solvent could be obtained without having the problem. However, the findings show that dichloromethane has many additives, some of which are listed as pollutants in the environment, to cause further problems in trace organic analyses.

With the closely related solvent, chloroform, degradation to phosgene and hydrogen chloride is well known, and ethanol at $0.5-1.0 \%$ is usually 


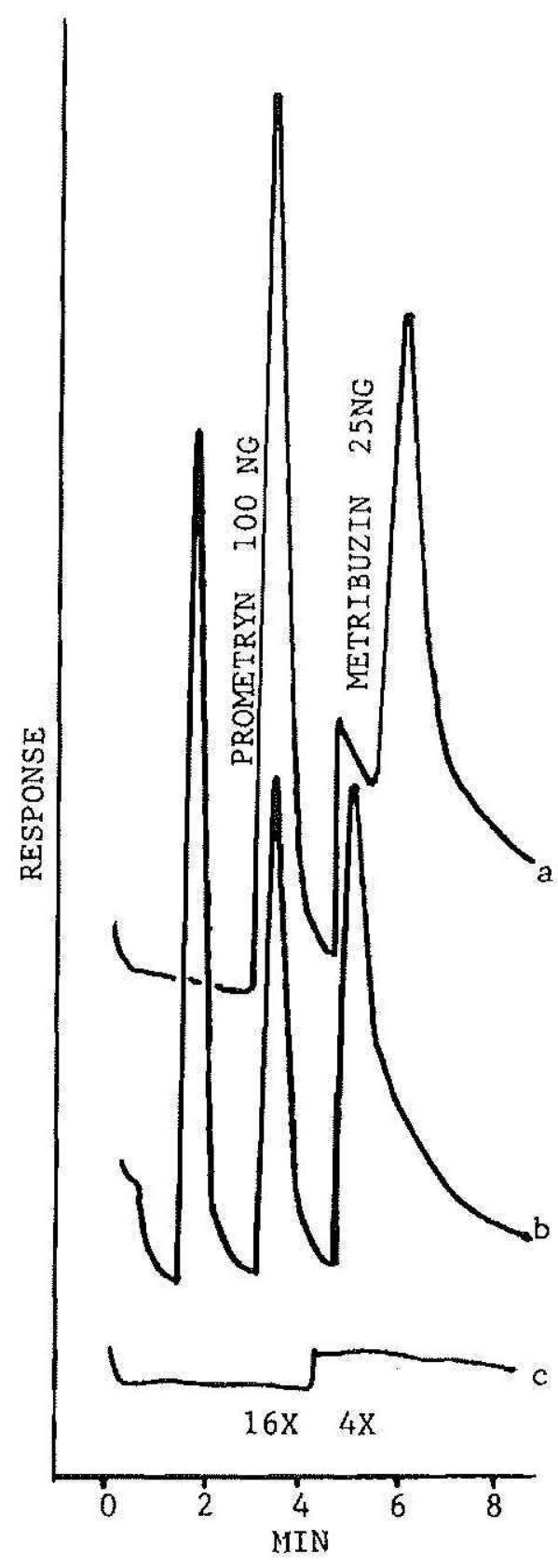

Fig. 7.-Chromatograms of extracts with cleaned (a) and uncleaned (b) dichlormethane of equally fortified Isabela soil samples with an unfortified sample (c). See Table 1 for percent recoveries.

added as preservative (5). Despite the similarities to chloroform, dichloromethane, which is noted to form chlorides and acidity on aging in one grade stated to be unstabilized (EM Science DX 0832), has not been subjected to a standard additive for stabilization or preservation. Catalogs from seven chemical supply companies showed that one grade of four from one company had $0.1 \%$ ethanol listed as a preservative. 


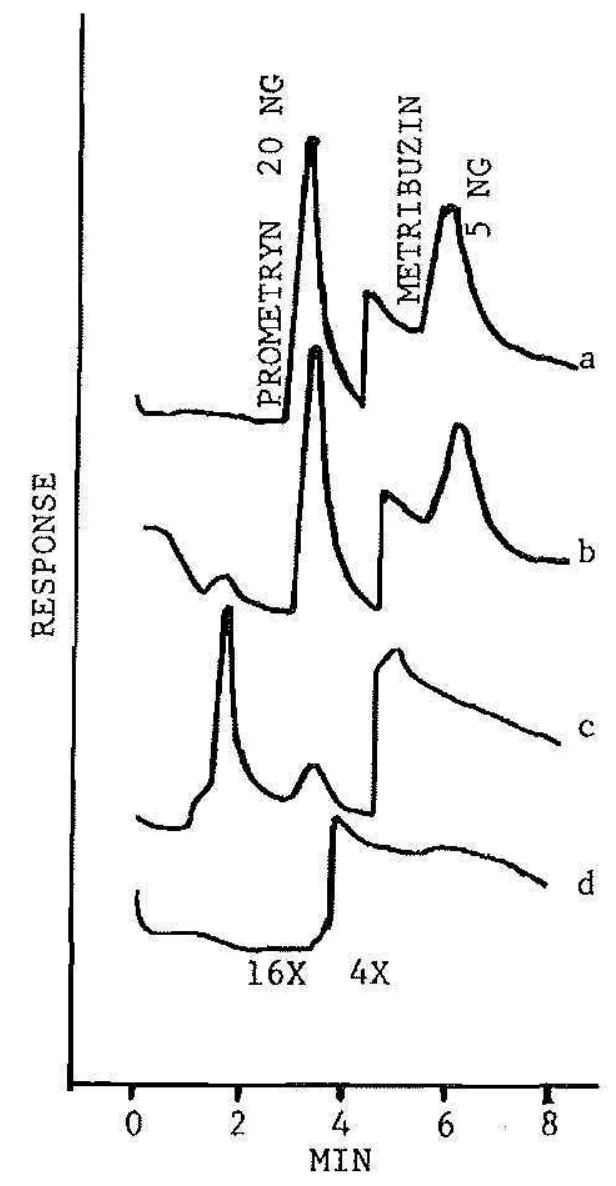

FIG. 8.-Chromatograms of standard (a) and extracts with cleaned (b) and uncleaned (c) dichloromethane of equally fortified Lajas soil samples with unfortified sample (d). See Table 1 for percent recoveries.

Three companies cited cyclohexane or one of several alkenes at 50-500 $\mathrm{p} / \mathrm{m}$ levels as additives, in most but not all their grades of dichloromethane, whereas three companies listed nine products without mentioning the presence or absence of additives. The Kirk-Othmer Encyclopedia of Chemical Technology, 3rd Ed., 1979 (4) indicated then that still other compounds, phenols, amines or a mixture of nitromethane and 1,4-dioxane, have also been used in dichloromethane as inhibitors at

TABLE 1. Percent recoveries of prometryn and metribuzin from two soils fortified at two levels for comparison of extractions by cleaned ( $\mathrm{Cl}$.) and uncleaned (Un.) dichromethane

\begin{tabular}{|c|c|c|c|c|c|c|}
\hline \multirow[b]{2}{*}{ Herbicide } & \multirow{2}{*}{$\begin{array}{l}\text { Level } \\
\text { fortified } \\
\text { in } \mathrm{p} / \mathrm{m}\end{array}$} & \multicolumn{2}{|c|}{$\begin{array}{c}\text { Lajas } \\
\text { Vertisol } \\
\text { percent }\end{array}$} & \multirow{2}{*}{$\begin{array}{c}\text { Level } \\
\text { fortified } \\
\text { in } p / m\end{array}$} & \multicolumn{2}{|c|}{$\begin{array}{l}\text { Isabela } \\
\text { Oxisol } \\
\text { Percent }\end{array}$} \\
\hline & & $\mathrm{Cl}$. & Un. & & Cl. & Un. \\
\hline Prometryn & 0.4 & 100 & 14 & 2.0 & 76 & 42 \\
\hline Metribuxin & 0.1 & 89 & 0 & 0.5 & 77 & 0 \\
\hline
\end{tabular}


levels reaching $1.0 \%$ in some cases. With such a variety of additives being used, anyone using dichloromethane may need much information to know which additive(s) will be acceptable for his planned use.

Very little information on the function and behavior of the additives is available according to one chemical supply company's technical representative, ${ }^{5}$ who said his company was initiating an investigation on additives because of a recent paper by Ibrahim et al. (3). This paper showed that cyclohexene at $50-100 \mathrm{p} / \mathrm{m}$ levels as a stabilizer in a high purity dichloromethane, when used to extract drinking water, reacted with free chlorine in the water to form mutagenic compounds that were originally considered as being in the water and not as artifacts from reactions of the stabilizer. No information could be found on how long each additive functions in its role of stabilizer, preservative or inhibitor before undesirable effects appear due to the additive being spent. Other points, on which no information could be found, were whether altered compounds might be formed from any additive in performing correctly whatever function it had in the solvent, and whether such altered compounds might then show up with time to interfere in analyses even though the dichloromethane had been maintained free of its degradation products.

With the dichloromethane used here, the brand is not mentioned aue to lack of comparative data with other brands stored for equivalent periods and lack of knowledge as to whether it is equivalent to the more recent product the company sells. With this one, the bottles of pesticide grade were purchased in 1978-81 with no label mention of additives, although a 1986 catalog of the company indicates added cyclohexane at $100-350 \mathrm{p} / \mathrm{m}$ levels as a preservative in this and other grades of its dichloromethane. According to a company technical representative ${ }^{6}$ its PG product was known to have cyclohexane as early as 1980 without its being listed on the label or in the company's catalog, but before that, its presence was not known for sure. The technical representative, when asked whether any information was available on how cyclohexane functioned as a preservative, indicated that he had none.

All these problems with stability, additives and altered additives, which chemical supply companies have not warned about, suggest that finding a substitute for dichloromethane as an extractive, chromatographic and spectroscopic solvent may be the one way to avoid the problems. Higher boiling chlorinated solvents such as 1,2-dichloroethane, B.P. $83.4^{\circ}$ C: 1,1-dichloroethane, B.P. $57^{\circ} \mathrm{C}$ : and 2,2-dichloropropane, B.P. $69^{\circ} \mathrm{C}$ appear feasible as possible substitutes, especially if any may be stable enough to avoid additives. Unfortunately, little data on toxicity

${ }^{\text {} P e r s o n a l ~ C o m m u n i c a t i o n ~ w i t h ~ D r . ~ G u n t h e r ~ N i e s s e n, ~ E M ~ S c i e n c e, ~ C h e r r y ~ H i l l, ~ N J, ~}$ 6 Oct. 1987.

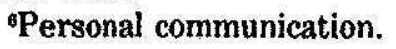


and stability are available at present for these alternative solvents as to whether any one of them might be better than dichloromethane. The work reported here and the review on additives warn that everyone using dichlormethane as a solvent should check carefully on whether additives present may cause problems in his planned work, especially in doing trace organic analyses such as pesticide residue work. Possibly, using an unstabilized dichloromethane that has been base-washed just before use, especially for extractions as developed in this work, may present fewer problems than using a grade with an additive.

\section{LITERATURE CITED}

1. Anderson, C. A., 1976. Sencor ${ }^{\$}$. In: Analytical Methods for Pesticides and Plant Growth Regulators, G. Zweig (Ed), Vol. III, pp 453-71, Academy Press, N.Y.

2. Anderson, R. J., 1980. Alternative approaches to the preparatin and care of the ion exchange bed for the 700A HECD, 1 page, Applications 80-5, Tracor Instruments, Austin, TX.

3. Ibrahim, E. A., R. L. Lippincott, L. Brenner, I. H. Suffet and R. E. Hannah, 1987. The effect of cyclohexene, a preservative in dichloromethane, on liquid-liquid extraction and analysis of chlorinated drinking water. J. Chrom. 393: 237-51.

4. Kirk-Othmer, 1979. Encyclopedia of Chemical Technology, 3rd ed, p. 686, John Wiley \& Sons, N.Y.

5. Landgrebe, J. A., 1982. Theory and Practice in Organic Chemistry, 3rd ed, pp 177-8, D. C. Health and Co., Lexington, MA.

6. Liu, L. C., H. R. Cibes-Viadé, and J. González-lbánez, 1971. Persistence of several herbicides in a soil cropped to sugarcane, $J$. Agric. Univ. P. R.., 55: 147-52.

7. Mattson, A. M., R. A. Kahrs and R. J. Murphy, 1970. Quantitative determination of triazine herbicides in soils by chemical analysis In: The Triazine Herbicides, Vol. 32, Residue Reviews, F. A. Gunther (Ed) pp 371-90, Springer-Verlag, N.Y. 